\title{
Internationaliseringsudfordringer afspejlet i Studiemiljø2011 på Aarhus Universitet: Der er stadig plads til forbedringer!
}

\author{
Karen M. Lauridsen, lektor, Center for Undervisning og Laring, Business and Social \\ Sciences, Aarhus Universitet. \\ Stacey Marie Cozart, sprogkonsulent i engelsk og teamleder for Sprogservice under \\ AU Kommunikation, Arts, Aarhus Universitet.
}

\section{Reviewet artikel}

Artiklen identificerer de uddannelseskulturelle og sproglige problemer som specielt de udenlandske studerende giver udtryk for i Studiemiljø2011, og som let opstår når man ikke er fuldt bevidst om hoad der er på spil i de internationale studieprogrammer. På baggrund af eksisterende litteratur på området diskuteres mulige løsninger på disse problemer for såvel undervisere som for universitetets ledelse.

\section{Introduktion}

I store dele af Europa er der gennem de seneste ti år sket en voldsom udvidelse af de engelsksprogede studieprogrammer (Wächter \& Maiworm, 2008); dette gælder også i Danmark (Danmarks Evalueringsinstitut, 2010). Denne proces har af mange været betragtet som uproblematisk, idet man gik ud fra at det var et spørgsmål om at oversætte materiale og hidtidig praksis til engelsk (jf. fx Hellekjær, 2010); men helt så enkelt er det ikke. Som det fremgår af Studiemiljø2011, kræver det ikke blot de nødvendige sproglige kompetencer hos både undervisere og studerende; det kræver også bevidsthed om andre faktorer i uddannelseskulturen, og denne bevidsthed kommer ikke nødvendigvis af sig selv.

I det følgende vil vi identificere de problemfelter som de udenlandske studerende har peget på i Studiemiljø2011. Disse afspejler faktorer der allerede er kendte i faglitteraturen, og vi kan derfor pege på mulige løsninger på de identificerede problemer på basis af denne samt egne observationer og erfaringer. På baggrund heraf vil vi således diskutere hvad universitetet og underviserne kan gøre for at afhjælpe disse problemer, samt pege på områder hvor der er behov for yderligere viden. De følgen- 
de afsnit tager således afsæt i undersøgelsen på AU, men der er grund til at antage at de identificerede problemstillinger også ses på andre danske universiteter.

Dette temanummer handler om studiemiljø og de studerendes trivsel. Dermed falder en række andre udfordringer som studerende og undervisere måtte opleve som resultat af internationaliseringen, uden for denne artikels rammer. Når vi taler om de studerendes trivsel, er det væsentligt at være opmærksom på om der er specifikke grupper af studerende hvis besvarelse er markant anderledes end studentergruppens som helhed. Oplysninger om etnicitet, religion, køn og seksuel orientering er indeholdt i Studiemiljø2011 (Aarhus Universitet, 2011a), men der er ikke spørgsmål om universitetets internationale programmer og de specielle forhold som kan gøre sig gældende der. De danske og udenlandske studerende blev bedt om at udfylde det samme spørgeskema i henholdsvis en dansk og en engelsk version, og der var ikke nogen kategorier af spørgsmål som direkte adresserede forhold i de engelsksprogede uddannelsesprogrammer hvor studerende og undervisere har forskellige sproglige og kulturelle baggrunde. Dette er naturligvis sket ud fra en grundlæggende præmis om at alle fuldtidsstuderende som deltog i undersøgelsen, skulle behandles ens. Alligevel har det vist sig at nogle udenlandske studerende ikke trives så godt som deres danske medstuderende, og at grundene hertil netop kan tilskrives sproglige og kulturelle forhold.

Hvad angår det helt overordnede udsagn 'Jeg føler mig generelt rigtig godt tilpas på mit studie', er 87 \% af de danske studerende helt eller overvejende enige, mens det tilsvarende tal for de udenlandske studerende er $79 \%$. Selv om denne forskel ikke synes alarmerende, er det alligevel værd at bemærke, ikke mindst da kun $27 \%$ af de udenlandske studerende er helt enige, hvorimod det for de danske studerende er 49 \% - relativt set næsten dobbelt så mange (Aarhus Universitet, 2011a:27). Der er altså væsentlige forskelle på de to grupper af studerende, og når man dykker lidt længere ned i undersøgelsen, afsløres det at en del udenlandske studerende føler sig diskriminerede og chikanerede, bl.a. fordi en del helt centrale informationer udelukkende er tilgængelige på dansk, og de studerende der ikke behersker dansk, dermed ikke har adgang til dem.

Disse resultater fra Studiemiljø2011 er som sådan ikke overraskende. Vi ved at det kræver en særlig opmærksomhed fra de studerende såvel som fra universitetet og underviserne at gennemføre internationale studieprogrammer på en sådan måde at alle studerende har så gode vilkår som overhovedet muligt. Det er dokumenteret i en del af den litteratur der foreligger om international uddannelse; en ikke ubetydelig del af denne har rod i den angelsaksiske verden hvor størstedelen af underviserne og de studerende har engelsk som første sprog, og hvor de udenlandske studerende forventes at tilpasse sig den engelsksprogede angelsaksiske uddannelseskultur (fx 
Carroll, 2002; Carroll \& Ryan, 2005; Hellstén \& Reid, 2008; Singh \& Doherty, 2004). I modsætning hertil er det i Danmark typisk kun et lille mindretal af undervisere og studerende der har engelsk som førstesprog. Det betyder at der her ud over de kulturelle og uddannelsesmæssige faktorer også er sproglige faktorer som skal tages i betragtning fordi de fleste skal undervise eller lære på et fremmedsprog.

\section{Diskriminering og chikane?}

Den mest påfaldende forskel mellem de danske og de udenlandske studerendes besvarelser i Studiemiljø2011 findes i afsnittet om diskriminering og chikane (Aarhus Universitet, 2011a, kapitel 7; 2011b, kapitel 7). Her spørges de studerende bl.a. om de inden for de seneste 12 måneder har været udsat for diskriminering på grund af deres etniske baggrund. Det svarer $2 \%$ af de studerende ja til, men dette tal dækker over store variationer idet $15 \%$ af de udenlandske studerende svarer bekræftende på dette spørgsmål. På Business and Social Sciences, det område som samlet set har over halvdelen af universitetets udenlandske studerende, er det endda $19 \%$. I absolutte tal betyder det at skønt det kun er hver tiende studerende der er af udenlandsk herkomst på universitetet og blandt de studerende som har deltaget i undersøgelsen, er to tredjedele af de studerende som har følt sig diskrimineret på grund af deres etniske baggrund, at finde blandt de udenlandske studerende (Aarhus Universitet, 2011a:51f). Spørgsmålet er nu hvad diskriminering og chikane dækker over i denne sammenhæng.

Det fremgår af undersøgelsens kvalitative materiale (rapportens opsummering af tekstkommentarerne) at der bl.a. er tale om følgende forhold: (1) De udenlandske studerende oplever de danske studerende som høflige og hjælpsomme, men ikke parate til at lukke udenlandske studerende ind i arbejdsgrupper, læsegrupper og sociale sammenhænge. (2) Selv om undervisningen foregår på engelsk, er megen information om administrative og sociale forhold kun tilgængelig på dansk. (3) Danske og udenlandske studerende stilles nogle gange forskelligt til eksamen, fx når danske studerende må aflevere opgaver på dansk og de udenlandske studerende af gode grunde skal aflevere på engelsk. (4) De udenlandske studerende møder et meget varieret niveau af engelsk blandt undervisere og medstuderende (Aarhus Universitet, 2011b:50).

Det er svært at vide om der er tale om bevidst diskriminering eller forsøg på chikane, men det ændrer ikke ved at det er sådan det bliver opfattet af de udenlandske studerende, eller også var det simpelthen her at de havde mulighed for at udtrykke de frustrationer som de oplever i deres dagligdag på universitetet. Under alle omstændigheder er det noget som universitetet og de enkelte undervisere må tage alvorligt. Lad os se på disse forhold et ad gangen. 


\section{Universitetet som en global kontaktzone}

Som et resultat af internationaliseringen har universitetet udviklet sig til et mødested for forskere, undervisere og studerende med meget forskellige sproglige og kulturelle baggrunde. Det er nu spørgsmålet hvorledes vi forvalter denne globale kontaktzone (Singh \& Doherty, 2004). Vi ser her bort fra de relativt få tilfælde hvor udenlandske studerende lærer og gennemfører en universitetsuddannelse på dansk, og fokuserer på de engelsksprogede internationale programmer. Her er spørgsmålet hvordan vi på den ene side lærer de udenlandske studerende at tilpasse sig en dansk uddannelseskultur (selvstændighed, projektarbejde, mundtlig eksamen etc.), og på den anden side lærer de danske studerende at deltage i et internationalt program. Dette indebærer bl.a. at alle studerende og undervisere i fællesskab skal konstruere universitetet som en global kontaktzone, et kulturmøde hvor alle kan lære af hinanden. Hvis dette kulturmøde, som må være en af grundpillerne i et internationalt program, ikke lykkes, er det sandsynligvis en af forklaringerne på at de udenlandske studerende ofte føler sig udenfor, jf. det første punkt ovenfor. De kom til Danmark med et ønske og en forventning om at deltage i den globale kontaktzone, men de danske studerende er kun i begrænset omfang parat til at deltage i dette fællesskab. Denne problemstilling er ikke ukendt og ses fx også i Danmarks Evalueringsinstitut (2010); Wilken (2007) og i en opfølgning på Studiemiljø2011 ( Larsen, Dahl \& Kusk 2011).

Et af de steder hvor dette problem bliver allermest tydeligt, er i samarbejde - herunder gruppearbejde - mellem studerende med meget forskellige baggrunde. Hvis ikke underviseren er opmærksom på denne problemstilling og eksplicit opstiller nogle begrundede kriterier for gruppedannelsen, vil de studerende næsten altid vælge at gå sammen med deres egne, typisk studerende med samme nationale og sproglige baggrund som dem selv, og dermed afskærer de sig fra at få udbytte af det som studerende med en anden sproglig og kulturel baggrund kunne bidrage med (Wilken, 2007). De afskærer sig fra at konstruere ny viden på et bredere, internationalt eller globalt grundlag.

Wilken (2007) påpeger endvidere hvorledes de udenlandske studerende har vanskeligt ved at få anerkendt deres viden som ligeværdig med de danske studerendes. Danske og (vestlige) udenlandske undervisere forfalder ofte til at henvise til forhold som er velkendte i en vestlig kontekst, men som man ikke kan tage for givet at studerende fra andre dele af verden kender til. Et oplagt eksempel herpå er naturligvis en henvisning til kulturelle traditioner i forbindelse med kristne højtider eller danske Skt. Hans-bål, men henvisninger til større virksomheder (Danfoss, Siemens, Procter \& Gamble, etc.) i forbindelse med undervisning i organisation og ledelse, EU-ret eller virksomhedskommunikation er andre eksempler herpå. Omvendt kender de danske (eller andre vestlige) undervisere og studerende som oftest ikke de tilsvarende hen- 
visninger til lande i Østeuropa, Sydamerika eller Asien, og derfor anerkender de ofte heller ikke sådanne eksempler som ligeværdige med deres egne.

Ovenstående skyldes ikke mindst at der ikke blot er sproglige og kulturelle forskelle mellem de studerende, de har også forskellige videnssystemer. Hvis de udenlandske studerende skal kunne afkode information i det der for dem er en fremmed samfundsmæssig og kulturel kontekst, kan de kun i begrænset omfang trække på den viden som de har med sig fra deres hjemlande, og de er nødt til - parallelt hermed at opbygge viden om danske (vestlige) samfundsmæssige og kulturelle forhold. Singh \& Shresta, (2008) taler om at de udenlandske studerende skal have en dobbelt viden (double knowing) for at blive anerkendt som en del af det vestlige akademiske diskursfællesskab (community of scholars), men hvis de udenlandske studerende virkelig skal være en del af en global kontaktzone, kræver det at universitetet bliver mere inkluderende og anerkender alle studerendes sproglige, kulturelle og vidensmæssige bagage som en værdi i de internationale programmer (Tange \& Kastberg, 2011). Og forfølger man denne tankegang og gør den til en del af universitetets internationaliseringspolitik, er det nødvendigt at styrke alle interessenters (studenters, underviseres og lederes) bevidsthed om hvad der kræves for at udvikle et egentligt internationalt universitet. Kun på den måde kan alle studerende deltage på lige fod i den globale kontaktzone.

\section{Sprogpolitik}

De to næste punkter i de studerendes kommentarer - at megen information kun foreligger på dansk og dermed ikke er tilgængeligt for de studerende som ikke behersker dansk, og at nogle danske studerende må aflevere opgaver, herunder eksamensopgaver, på dansk, også selv om de deltager i engelsksprogede programmer - kan dels ses i forlængelse af ovenstående diskussion om hvorledes alle studerende bliver inkluderet i universitetets globale kontaktzone, dels ses som et udslag af en manglende konsistent gennemført sprogpolitik på universitetet. Disse to punkter er i sig selv også tæt forbundne.

Vi ved af erfaring og fra litteraturen (fx Airey \& Linder, 2006; Danmarks Evalueringsinstitut, 2010) at de studerende i mange tilfælde er tilbageholdende med at stille spørgsmål og deltage i diskussioner når undervisningen foregår på engelsk. De holder sig i stedet tilbage og stiller herefter spørgsmål direkte til underviseren i en pause. Danske studerende kommunikerer her ofte med de danske undervisere på dansk. Mange vil opfatte dette som naturligt da de to kommunikationspartnere blot benytter deres fælles førstesprog, men de overser at de udenlandske studerende stilles uden for dette diskursfællesskab, og at de danske studerende dermed også får mere favorable vilkår for deres læring idet den vidensopbygning som de her er i gang med, kan foregå på deres førstesprog og ikke gennem et fremmedsprog. Derfor op- 
fatter de udenlandske studerende også dette som diskrimination idet de ikke har samme muligheder for at lære på deres førstesprog. Der bør derfor være en helt fast konsensus om at undervisningssproget hele tiden er engelsk på de internationale programmer.

Dette gælder naturligvis både selve undervisningssituationen og den litteratur og de øvrige referencer der henvises til. At de studerende så, fx i et projektarbejde, kan henvise til kilder på andre sprog og dermed bringe viden fra deres egen sproglige og kulturelle baggrund i spil, er en anden sag (jf. diskussionen i afsnittet om den globale kontaktzone ovenfor). Endelig, og ikke mindst, er det afgørende at de studerende er stillet så lige som muligt hvad angår eksamen. Derfor bør undervisnings- og eksamenssprog også være det samme, og det bør være et ufravigeligt krav at eksamensopgaver og -besvarelser alle er på engelsk i de internationale programmer. Som det fremgår af disse eksempler på forskelsbehandling af de danske og udenlandske studerende, er der behov for nogle klare retningslinjer på dette område. Der er således brug for en eksplicit sprogpolitik der bliver implementeret og overholdt på hele universitetet. Det er endvidere et af de områder hvor der er behov for at få samlet viden og erfaringer således at universitetet har et solidt grundlag for at udarbejde en sådan sprogpolitik.

\section{Sprog- og kommunikationsfærdigheder}

Det fjerde punkt fra de studerendes kommentarer - det forhold at nogle oplevede et varierende niveau i engelsk blandt undervisere og medstuderende - er som sådan ikke nødvendigvis en kvalitetsvurdering af den engelsksprogede undervisning. Det er dog vigtigt at bemærke at de seneste års empiriske undersøgelser af engelsksproget undervisning på universiteter i Norden har vist at sproglige udfordringer hos undervisere eller studerende kan påvirke undervisning og læring negativt (fx Airey \& Linder, 2006; Danmarks Evalueringsinstitut, 2010; Hellekjær, 2010; Tange, 2010a \& b). Det er derfor nærliggende at udlede at utilstrækkelige sproglige og kommunikative kompetencer også har været den reelle baggrund for de udenlandske studerendes kommentarer i Studiemiljø2011. I forlængelse heraf vil vi derfor fremhæve nogle af de udfordringer som vi ved studerende og undervisere kan møde på grund af utilstrækkelige sprog- og kommunikationsfærdigheder, og som kan have indflydelse på kvaliteten af undervisning og læring i engelsksprogede undervisningsforløb.

Hvis vi først fokuserer på studerendes faglige udbytte og oplevelse af undervisning på engelsk, har flere nordiske empiriske undersøgelser vist at et betragteligt antal universitetsstuderende ikke har de nødvendige sprogfærdigheder til at følge engelsksproget undervisning (Airey, 2010; Airey \& Linder, 2006; Hellekjær, 2010). I Aireys og Hellekjærs undersøgelser i henholdsvis Sverige og Norge kom dette bl.a. til udtryk ved at de studerende generelt havde svært ved at følge forelæsninger på 
grund af undervisernes problemer med udtale og/eller forekomsten af ukendt terminologi. Desuden oplevede de besvær med at følge forelæsninger og tage noter samtidigt og med at fange selv hovedpointerne i en forelæsning.

Ud fra nordiske empiriske undersøgelser af underviseres oplevelser af engelsksproget undervisning kan vi iagttage en tendens til at underviserne selv opfatter deres kommunikation på engelsk som mere simpel og mindre præcis og varieret end på deres førstesprog; dette er dels et resultat af deres egne sproglige udfordringer, dels en strategi for at imødekomme de studerendes utilstrækkelige sprogkompetencer (Hellekjær, 2010; Hellekjær \& Westergaard, 2003; Tange, 2010a \& b). Nogle undervisere har også givet udtryk for at de bruger færre eksempler, og at de i det hele taget føler sig sprogligt hæmmet, hvilket kommer til udtryk i en mere formel, akademisk tone og dermed i en mindre levende og afvekslende undervisning med færre forekomster af uformelle, dialogiske udvekslinger mellem underviser og studerende (Hellekjær, 2010; Tange, 2010a \& b). Endvidere har EVA-undersøgelsen af engelsksprogede kandidatuddannelser i Danmark vist at nogle undervisere har oplevet problemer med at udtale ord korrekt og klart samt at huske ord og udtryk (Danmarks Evalueringsinstitut, 2010).

Det er interessant at bemærke at Airey og Linders (2006) undersøgelse af 23 fysikstuderende i Sverige fandt at de fleste studerende umiddelbart vurderede at der ikke var en nævneværdig forskel mellem at lære gennem engelsk og at lære gennem deres førstesprog. Derimod viste undersøgelsens empiriske datasæt det modsatte, nemlig at de studerendes læring bl.a. var påvirket af de ovenfor nævnte forståelsesproblemer. Derfor kan der være grund til at grave lidt dybere i EVA-undersøgelsen, hvor flertallet af de adspurgte undervisere og studerende hævder at kvaliteten af kandidatundervisningen i Danmark ikke påvirkes negativt af at den foregår på engelsk (Danmarks Evalueringsinstitut, 2010). Der er med andre ord behov for mere evidensbaseret viden om hvordan kvaliteten af undervisning og læring påvirkes når undervisningen foregår på engelsk.

\section{Tydelig og effektiv kommunikation}

På baggrund af de ovenfor nævnte faktorer kan tydelig og effektiv kommunikation således som det er eksemplificeret nedenfor - fremhæves som et enkelt middel, som underviserne med fordel kan anvende hvis kvaliteten af universiteternes engelsksprogede uddannelser skal udvikles og fremtidssikres. De kommunikationsproblemer der gør sig gældende i undervisningen på et givet førstesprog, forstærkes når undervisningssproget ændres til et fremmedsprog som fx engelsk, og derfor kan de følgende anbefalinger også ses som væsentlige ved undervisning på de studerendes førstesprog (Airey \& Linder, 2006; Hellekjær, 2010). 
Det er således særligt vigtigt at underviserne afhjælper den kognitive belastning som studerende kan opleve når de skal afkode sproget, tage noter og følge den røde tråd i undervisningen samtidig (Björkman, 2010; Hellekjær, 2010). Til det formål kan underviserne bruge et aktivt og præcist sprog uden for mange metaforer og idiomer eller for meget jargon som det kan være svært for mange med engelsk som fremmedsprog at forstå. Det betyder dog ikke at sproget skal være simpelt, men at det mere enkle i stigende grad skal forenes med det mere komplekse for at give de studerende mulighed for at styrke deres akademiske sprogfærdigheder og oparbejde en fortrolighed med den faglige diskurs i løbet af deres uddannelse. Undervisere kan desuden afhjælpe forståelsesproblemer ved at udlevere (trykt eller elektronisk) materiale i form af termlister, slides, arbejdsark etc. og ved at tale langsomt og holde pauser undervejs; dette giver de studerende mulighed for at tænke videre over vigtige pointer - eller for bare at holde en nødvendig pause (Airey \& Linder, 2006; Hellekjær, 2010).

Forskning i forelæsninger med engelsk som lingua franca ved et teknisk universitet i Sverige indikerer endvidere at underviserne kan gøre deres forelæsninger mere interaktive og dermed mere forståelige ved at bruge en række pragmatiske strategier og at sådanne strategier er vigtigere for at øge de studerendes faglige forståelse end et højt sprogligt niveau hos underviseren (Björkman, 2010; Hellekjær, 2010 ). En meget effektiv, men enkel, pragmatisk strategi er fx at tydeliggøre rammen omkring undervisningen og at vise, hvordan emnet hænger sammen med andre emner i forløbet. Det indebærer også brugen af forskellige diskursmarkører for at føre de studerende gennem forelæsningen eller holdtimen ( $f x$ Let's start by ..., We've considered..., Moving on to..., Let's summarize what we've covered...).

Undervisere kan bl.a. også med fordel fremhæve, gentage og forklare vigtige begreber og hovedpointer samt stille spørgsmål som fremmer de studerendes involvering i undervisningen (Björkman, 2011; Hellekjær, 2010; Morell, 2004).

\section{Hvad kan og bør universiteterne gøre?}

En af de måder hvorpå man kan løse de problemer som internationaliseringen indebærer, dens positive aspekter ufortalt, er at klæde underviserne bedre på til at tackle dem. Som allerede nævnt peger danske og internationale forsknings- og udviklingsprojekter på en række centrale faktorer som man med fordel kan være opmærksom på; en del af disse har vi allerede omtalt i det foregående. Det danske udviklingsprojekt Internationalisering af uddannelserne: En udfordring for universiteternes undervisere som er blevet gennemført i 2010-12 af medarbejdere på seks danske universiteter, har netop til formål at identificere de sproglige, kulturelle og pædagogiskdidaktiske problemer og foreslå løsninger der fungerer i en dansk kontekst. Dette 
projekts resultater kan derfor på flere måder bl.a. ses som et bidrag til at imødegå den chikane og diskriminering som de udenlandske studerende oplever.

På baggrund af de problemer med trivsel blandt udenlandske studerende som blev identificeret i Studiemiljø2011, har Aarhus Universitet i 2011 afsat midler til en række opfølgningsprojekter der har til formål at afhjælpe disse problemer. Et konkret eksempel herpå er en videreudvikling og oversættelse af Studiemetro til engelsk, en webressource der primært er udviklet til studerende inden for de humanistiske fag, men som også kan bruges af studerende generelt (Aarhus Universitet, Arts, u.å.). Denne samlede indsats fra universitetets side er væsentlig og skal fortsættes hvis vi skal sikre kvaliteten af de internationale uddannelser. Det er imidlertid også vigtigt at understrege behovet for en mere holistisk tilgang til internationalisering som tager hensyn til alle ansattes og studerendes behov for internationale og interkulturelle kompetencer hvis universitetet skal leve op til målsætningen om at være et fuldt ud internationaliseret universitet, og ikke mindst hvis de studerende skal erhverve sig de nødvendige kompetencer til at fungere i en global og interkulturel verden (jf. også Otten, 2003; Nilsson, 2003).

\section{Konklusion}

Hellekjær (2010) gør opmærksom på at kvaliteten af de engelsksprogede programmer ofte har lidt under at de ikke er blevet udviklet med skyldigt hensyn til de praktiske og pædagogiske vanskeligheder der er forbundet med at undervise og lære på et fremmedsprog. I denne artikel har vi identificeret og diskuteret nogle af disse vanskeligheder på baggrund af Studiemiljø2011. Alle, både undervisere og studerende, bringer en tavs viden med sig som er afgørende for de forventninger de gensidigt har til hinanden, og hvis ikke disse forventninger bliver afstemt i den nye flerkulturelle kontekst, opstår der meget nemt konflikter af den ene eller den anden art. Dette forhold er ikke unikt for $\mathrm{AU}$, men ses også på andre universiteter.

Vi har ovenfor givet nogle løsningsforslag som kan hjælpe såvel danske som udenlandske undervisere og studerende. Der er dog ingen tvivl om at AU og de øvrige danske universiteter fortsat har brug for at have fokus på de udfordringer der ligger i virkelig at internationalisere forskning og undervisning. Specielt hvad angår det sidste, er der dels behov for yderligere evidensbaseret forskning i Danmark, dels behov for en øget bevidsthed blandt undervisere og studerende om hvad en egentlig international uddannelse - og ikke blot en engelsksproget uddannelse - i virkeligheden indebærer. Som følge heraf vil mange undervisere have behov for kompetenceudvikling; dette kan naturligvis opnås gennem specielt tilrettelagte kurser under de universitetspædagogiske enheder, men de ovenfor nævnte strategier kan også hjælpe dem på vej. Endvidere kan underviserne på basis af egne erfaringer, og sammen med 
den evidensbaserede forskning, hjælpe universiteterne til at træffe beslutninger vedr. internationaliseringspolitik og sprogpolitik på et informeret grundlag.

Stacey M. Cozart er cand.mag. i Fransk og Engelsk og master i Fremmedsprogspædagogik. Hun er ansat som sprogkonsulent $i$ engelsk og teamleder for Sprogservice under AU Kommunikation, Arts, på Aarhus Universitet. Her arbejder hun bl.a. med at udvikle og afholde workshops og kurser $i$ akademisk engelsk for forskere, undervisere og ph.d.-studerende. Hun er særligt interesseret $i$ udvikling af underviseres og studerendes sproglige, kommunikative og interkulturelle kompetencer $i$ forbindelse med international undervisning. Hun sidder i styregruppen for det tværuniversitære projekt Internationalisering af uddannelserne: Udfordringer for universiteternes undervisere (2010-12).

Karen M. Lauridsen er cand. mag. i Engelsk og Tysk og ansat som lektor på Center for Undervisning og Laring på Aarhus Universitet, Business and Social Sciences (CUL). Hun har mere end tyve års erfaring med internationalisering af uddannelser og har i den forbindelse også deltaget $i$ en lang række europæiske udviklingsprojekter. På CUL arbejder hun især med forskning og undervisning inden for disse områder og har bl.a. udviklet et kursus, Teaching in English in the Multicultural Classroom. Hun sidder i styregruppen for det tværuniversitære projekt Internationalisering af uddannelserne: Udfordringer for universiteternes undervisere (2010-12).

\section{Referencer}

Aarhus Universitet (2011a). Studiemiljø2011. Undersøgelse af studiemiljøet ved Aarhus Universitet. Rapport nr. 1 / Aarhus Universitet. http://www.e-pages.dk/aarhusuniversitet/230/

Aarhus Universitet (2011b). Studiemiljø2011. Undersøgelse af studiemiljøet ved Aarhus Universitet. Rapport nr. 4 / Business and Social Sciences. http://www.e-pages.dk/aarhusuniversitet/233/

Aarhus University, Arts (u.å). Study Metro. http://studiemetro.au.dk/en/

Airey, J. \& Linder, C. (2006). Language and the experience of learning university physics in Sweden. European Journal of Physics 27(3).

Airey, J. (2010). The Ability of Students to Explain Science Concepts in Two Languages. Hermes - Journal of Language and Communication Studies 45. Aarhus School of Business, Aarhus University.

Björkman, B. (2010). So You Think You Can ELF: English as a Lingua Franca as the Medium of Instruction. Hermes - Journal of Language and Communication Studies 45. Aarhus School of Business, Aarhus University.

Björkman, B. (2011). Pragmatic strategies in English as a lingua franca: Ways of achieving communicative effectiveness? Journal of Pragmatics 43, 4.

Carroll, J. (2002). Suggestions for Teaching International Students More Effectively. Oxford Centre for Staff and Learning Development. Learning and Teaching Briefing Papers Series. Oxford Brookes University. http://www.brookes.ac.uk/services/ocsld/resources/briefing papers/internation al students.pdf 
Carroll, J. \& Ryan J. (eds.) (2005). Teaching International Students. Improving Learning for All. Oxon: Routledge.

Danmarks Evalueringsinstitut (2010). Engelsksproget undervisning på danske kandidatuddannelser. http://www.eva.dk/projekter/2009/undervisningen-paaengelsksprogede-uddannelser/projektprodukter/engelsksproget-undervisningpaa-danske-kandidatuddannelser.

Hellekjær, G. O. (2010). Lecture Comprehension in English-Medium Higher Education. Hermes - Journal of Language and Communication Studies 45. Aarhus School of Business, Aarhus University.

Hellstén, M. \& Reid, A. (eds.) (2008). Researching International Pedagogies. Sustainable Practice for Teaching and Learning in Higher Education. Springer.

Higher Education Academy (u.å.). Teaching International Students. http://www.heacademy.ac.uk/teaching-international-students.

Internationalisering af uddannelserne: Udfordringer for universiteternes undervisere. Et tvær-universitært udviklingsprojekt støttet af Statens Center for Kompetenceudvikling (u.å.). http://www.intluniversity.dk.

Larsen, M. D., Dahl, A. \& Kusk, M. L. (2011). Integration of international students at Aarhus University. Resumé of three focus group interviews (fall 2011).

http://prezi.com/mefnln10oh5e/au-international-study-environment-smu-2011/

Morell, T. M. (2004). Interactive lecture discourse for university EFL students. English for Specific Purposes 23.

Nilsson, B. (2003).Internationalisation at Home From a Swedish Perspective: The Case of Malmö. Journal of Studies in International Education 7 (1).

Otten, M. (2003). Intercultural Learning and Diversity in Higher Education. Journal of Studies in International Education 7 (1).

Singh, P. \& Doherty, C. (2004). Global Cultural Flows and Pedagogic Dilemmas:

Teaching in the Global University Contact Zone. TESOL Quarterly 38 (1).

Singh, P. \& Shresta, M. (2008). International Pedagogical Structures. Admittance into the Community of Scholars via Double Knowing. Chapter 4 in Hellstén \& Reid (2008).

Tange, H. (2010a). Undervisererfaringer med internationalisering. Aarhus School of Business, Aarhus University.

http://www.asb.dk/fileadmin/www.asb.dk/omasb/nyheder/nyhed/artikel/ny r apport skaev kritik af internationale studerende/fileexplorer fetchfile-aspxfile-17068.pdf

Tange, H. (2010b). Caught in the Tower of Babel: university lecturers' experiences with internationalisation. Language and Intercultural Communication 10 (2).

Tange, H. \& Kastberg P. (2011). Coming to terms with 'double knowing': an inclusive approach to international education. International Journal of Inclusive Education. 
Wächter, B. \& Maiworm F. (2008). English-Taught Programmes in European Higher Education. ACA Papers on International Cooperation in Education. Bonn: Lemmens.

Wilken, L. (2007). Når kultur kommer i vejen. Kapitalmøder og kulturforståelser på en international uddannelse i Danmark. Tidsskriftet Antropologi 56. 